\title{
Modulation of the firing activity of female dorsal raphe nucleus serotonergic neurons by neuroactive steroids
}

\author{
M Robichaud and G Debonnel \\ Department of Psychiatry, McGill University, 1033 Pine Avenue West, Montréal, Québec, Canada H3A 1A1 \\ (Requests for offprints should be addressed to G Debonnel; Email: guy.debonnel@mcgill.ca)
}

\begin{abstract}
Important gender differences in mood disorders result in a greater susceptibility for women. Accumulating evidence suggests a reciprocal modulation between the 5hydroxytryptamine (5-HT) system and neuroactive steroids. Previous data from our laboratory have shown that during pregnancy, the firing activity of $5-\mathrm{HT}$ neurons increases in parallel with progesterone levels. This study was undertaken to evaluate the putative modulation of the 5-HT neuronal firing activity by different neurosteroids. Female rats received i.c.v. for 7 days a dose of $50 \mu \mathrm{g} / \mathrm{kg}$ per day of one of the following steroids: progesterone, pregnenolone, $5 \beta$-pregnane-3,20-dione (5 5 -DHP), $5 \beta$ -

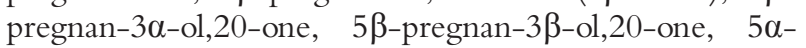
pregnane-3,20-dione, $5 \alpha$-pregnan- $3 \alpha$-ol,20-one (allopregnanolone, $3 \alpha, 5 \alpha-\mathrm{THP})$, $5 \alpha$-pregnane- $3 \beta$-ol,20-one and dehydroepiandrosterone (DHEA). $5 \beta-$ DHP and DHEA were also administered for 14 and 21 days $(50 \mu \mathrm{g} /$
\end{abstract}

$\mathrm{kg}$ per day, i.c.v.) as well as concomitantly with the selective sigma $1\left(\sigma_{1}\right)$ receptor antagonist NE-100. In vivo, extracellular unitary recording of 5-HT neurons performed in the dorsal raphe nucleus of these rats revealed that DHEA, $5 \beta$-DHP and $3 \alpha, 5 \alpha$-THP significantly increased the firing activity of the 5-HT neurons. Interestingly, $5 \beta-\mathrm{DHP}$ and DHEA showed different timeframes for their effects with $5 \beta$-DHP having its greatest effect after 7 days to return to control values after 21 days, whereas DHEA demonstrated a sustained effect over the 21 day period. NE-100 prevented the effect of DHEA but not of $5 \beta-\mathrm{DHP}$, thus indicating that its $\sigma_{1}$ receptors mediate the effect of DHEA but not that of $5 \beta$-DHP. In conclusion, our results offer a cellular basis for potential antidepressant effects of neurosteroids, which may prove important particularly for women with affective disorders. Journal of Endocrinology (2004) 182, 11-21

\section{Introduction}

There are important gender differences in susceptibility for mood disorders. Women experience depressive episodes earlier in life, more frequently, more recurrently and more persistently than men (Weissman \& Klerman 1977, 1985, Maes et al. 1986, Parry 1989, Hamilton 1993, Kessler et al. 1994, Weissman et al. 1996, Kornstein 1997, Joffe \& Cohen 1998). The mechanisms underlying these gender differences are not understood. It has been suggested that the frequent hormonal variations experienced by women might contribute to their vulnerability to depression (Endicott 1993, Pajer 1995, Kornstein 1997, Joffe \& Cohen 1998). Although the etiology of major depression remains unclear, the enhancement of serotonergic (5hydroxytryptamine (5-HT)) neurotransmission observed with antidepressant treatments suggests the implication of the 5-HT system in the biology of depression (Blier \& de Montigny 1999, Racagni \& Brunello 1999).

Ovarian steroids are known to affect brain areas not directly related to reproductive functions, such as the dorsal raphe nuclei (DRN) (McEwen et al. 1998). This nucleus being a region rich in 5-HT neuron cell bodies, ovarian steroids may have a functional impact on the 5-HT system. Numerous studies, performed in females, indicate that ovarian steroids modulate the expression of several genes of the 5-HT system (e.g. tryptophan hydroxylase, vesicular monoamine transporter, serotonin reuptake transporter and different 5 -HT receptors) (see review by Bethea et al. 1999).

Moreover, there is accumulating evidence suggesting that depressive states may be associated with a decrease

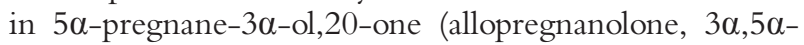
THP) levels. For instance, in a mouse model of depression, long-term social isolation decreases the cortical levels of $3 \alpha, 5 \alpha$-THP and $5 \alpha$-pregnane-3,20-dione ( $5 \alpha-\mathrm{DHP})$ (Dong et al. 2001). Also, the levels of $3 \alpha, 5 \alpha-$ THP and $5 \beta$-pregnane- $3 \alpha-\mathrm{ol}, 20$-one $(3 \alpha, 5 \beta-\mathrm{THP})$ were shown to be significantly lower in the cerebrospinal fluid (CSF) and plasma of depressed patients as compared with controls (Romeo et al. 1998, Uzunova et al. 1998). Conversely, selective serotonin reuptake inhibitors (SSRIs) have been shown to increase the cerebral content of some neuroactive steroids in both rats and humans (Uzunov et al. 
1996, Griffin \& Mellon 1999, Serra et al. 2001). Furthermore, successful antidepressant treatments not only regularize the levels of neuroactive steroids, but the extent of the increase in CSF contents of $3 \alpha, 5 \alpha-$ THP and $3 \alpha, 5 \beta-$ THP is also proportional to the mood improvement (Romeo et al. 1998, Uzunova et al. 1998).

Using an in vivo electrophysiological paradigm of extracellular recordings, we have previously shown that the spontaneous firing activity of DRN 5-HT neurons is significantly higher in male than in female rats, while ovariectomy (OVX) did not significantly modify the female 5-HT neuronal basal firing rate. Interestingly, during pregnancy, the spontaneous firing rate increased gradually to peak at the 17th day of pregnancy and then declined before parturition, thus following circulating levels of progesterone (but not of estrogen) (Klink et al. 2002).

Furthermore, we showed that, during pregnancy, $5-\mathrm{HT}_{1 \mathrm{~A}}$ autoreceptors were partly desensitized and that 5-HT neurons were probably under a much lower $\gamma$-aminobutyric acid (GABA)ergic tonic inhibition as compared with that of freely cycling females (FC) (Robichaud et al. 2002). Both of these functional modifications are consistent with the enhanced firing activity of 5-HT neurons observed during pregnancy. They also provide possible mechanisms by which hormonal fluctuations can modulate 5-HT neuron function and influence women's vulnerability to mood disorders.

Taken together, the literature and our previous data suggest a reciprocal modulation between the 5-HT system and neuroactive steroids. Therefore, the goal of the present studies was to assess a possible modulation of 5-HT neuron firing activity by progesterone and its metabolites (see Fig. 1).

\section{Materials and Methods}

\section{Animals}

Sprague-Dawley rats (Charles-River, St-Constant, Québec, Canada) weighing between 250 and 325 g were kept under standard laboratory conditions $(12 \mathrm{~h}$ light: $12 \mathrm{~h}$ darkness cycle with free access to food and water). FC and OVX females were used for the experiments. Ethical committee approval was obtained from the McGill University Animal Ethical Care Committee and all their rules and regulations were followed. The suffering of animals as well as the number used was kept at a minimum.

\section{Treatment with inhibitors of progesterone synthesis and metabolism}

OVX females operated at their 8th week of life were used for treatments with trilostane and finasteride. Trilostane treatments began at the 9th week of life. Trilostane suspended in sesame oil was administered by daily s.c. injections of $25 \mathrm{mg} / \mathrm{kg}$ for 14 days. Finasteride treatments began at the 10th week of life. Finasteride suspended in $1.5 \%$ methylcellulose was administered for 5 days by daily gavage of $20 \mathrm{mg} / \mathrm{kg}$. These doses of finasteride and trilostane have previously been shown to efficiently inhibit the $5 \alpha$-reductase and $3 \beta$-hydroxysteroid dehydrogenase (3 $\beta$-HSOD) enzymatic activities respectively (Potts et al. 1978, Young et al. 1994, Phan et al. 1999, Micevych et al. 2003). Experiments were carried out on the day following the last administration of either drug.

\section{Treatments with steroids}

All steroids were dissolved in 3\% (v/v) ethanol/distilled water and administered i.c.v. continuously by mean of an s.c. osmotic minipump connected to a cannula (ALZA, Palo Alto, CA, USA), which was implanted in the left lateral ventricle of the rat brain. The surgery was performed as described by the manufacturer (ALZA) and under chloral hydrate anesthesia. Each steroid was administered at a dose of $50 \mu \mathrm{g} / \mathrm{kg}$ per day. NE-100 (N,N-dipropyl-2-(4-methoxy-3-(2-phenylethoxy)phenyl)ethylamine), a sigma $1\left(\sigma_{1}\right)$ receptor antagonist, was dissolved in distilled water and administered s.c. by an osmotic minipump for a daily dose of $10 \mathrm{mg} / \mathrm{kg}$.

FC received one of the following treatments: 7,14 or 21 days with either $5 \beta$-pregnane-3,20-dione (5 $\beta$-DHP) or dehydroepiandrosterone (DHEA); 7 days with either progesterone, pregnenolone (PREG), $3 \alpha, 5 \beta-\mathrm{THP}, 5 \beta-$ pregnane- $3 \beta$-ol, 20 -one $(3 \beta, 5 \beta$-THP), $5 \alpha$-DHP, $3 \alpha, 5 \alpha-$ THP or $5 \alpha$-pregnane- $3 \beta$-ol, 20 -one $(3 \beta, 5 \alpha-\mathrm{THP}) ; 7$ days with either $5 \beta$-DHP or DHEA concomitantly with NE100. A first control for the surgical procedure was obtained with i.c.v. administration of saline for 7 days. A second series of controls received 3\% ethanol, i.c.v., for 7 days. Experiments were carried out the day following the last day of administration and after removal of the cannulae. Following experiments, every brain was removed, frozen at $-80{ }^{\circ} \mathrm{C}$ and sliced using a microtome to confirm the position of both the cannula and the recording electrode.

\section{Electrophysiological experiments}

All rats were anesthetized by an i.p. injection of chloral hydrate $(400 \mathrm{mg} / \mathrm{kg})$ and additional doses of $100 \mathrm{mg} / \mathrm{kg}$ were administered when needed. Rats were immobilized in a stereotaxic apparatus and their body temperature was maintained at approximately $37^{\circ} \mathrm{C}$ throughout the experiment by a thermistor-controlled heating pad.

Extracellular unitary recording of serotonergic neurons were conducted with single-barreled glass micropipettes pulled in a conventional manner, filled with a $1 \mathrm{M} \mathrm{NaCl}$ solution and of final impedance ranging between 2 and $6 \mathrm{M} \Omega$. A $4 \mathrm{~mm}$ diameter hole was drilled in the skull of each rat at the appropriate location (about $1 \mathrm{~mm}$ anterior of 


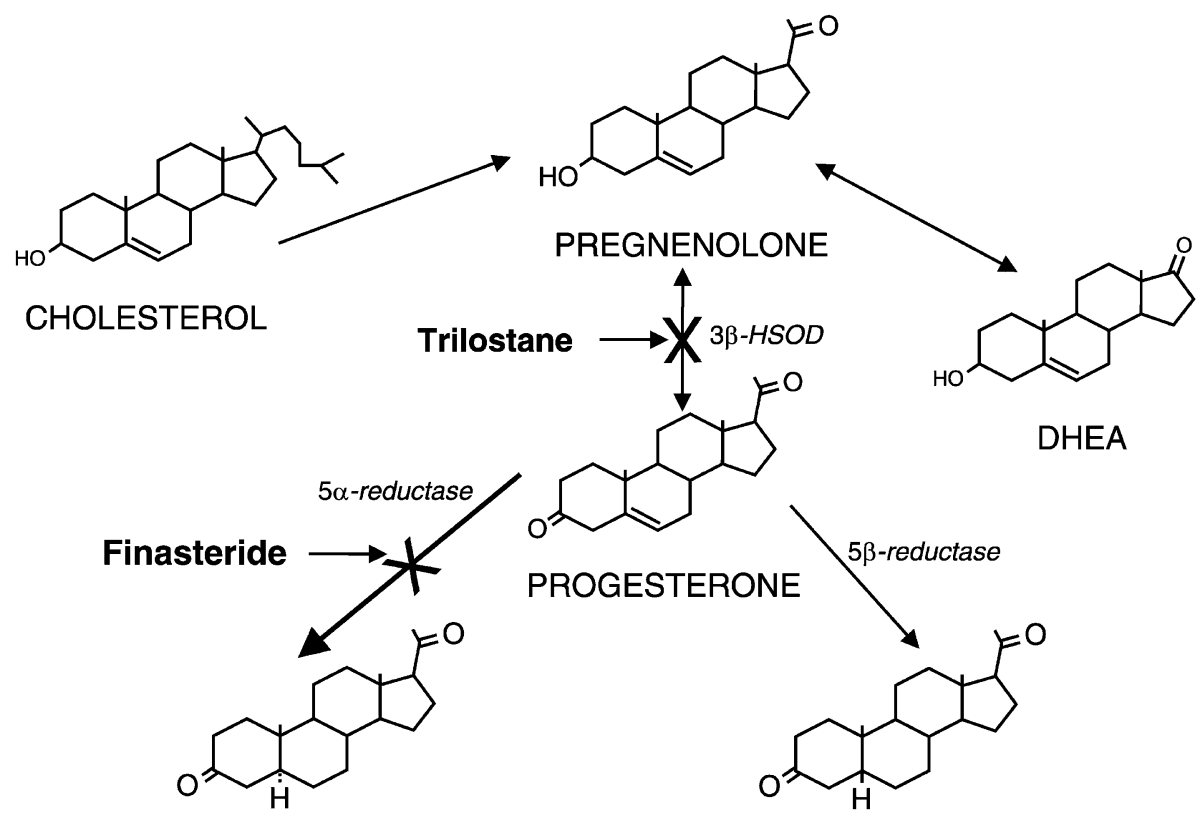

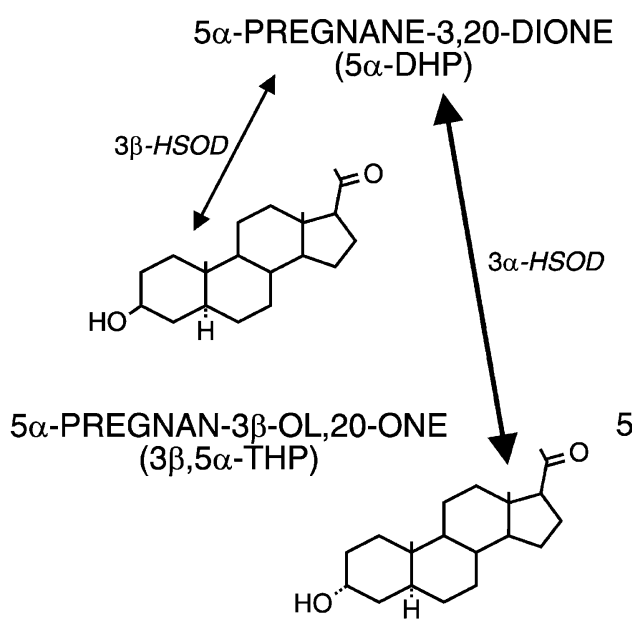

$5 \alpha$-PREGNAN-3 $\alpha-O L, 20-O N E$ $(3 \alpha, 5 \alpha-\mathrm{THP})$

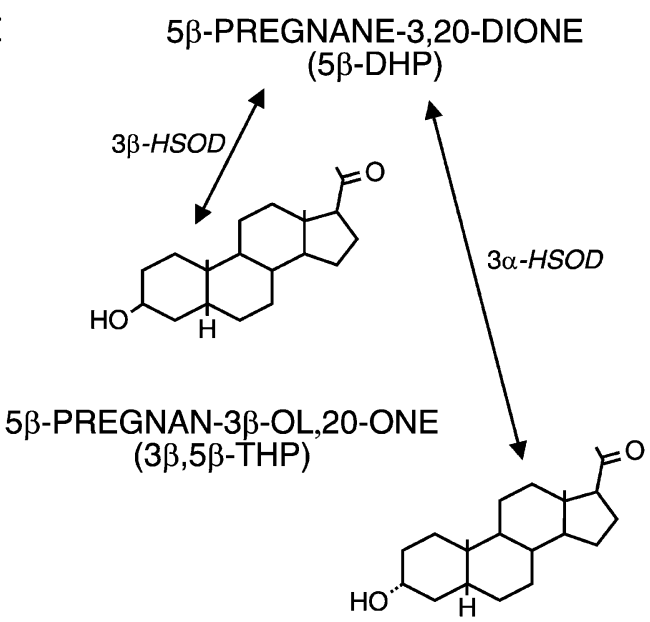

$5 \beta$-PREGNAN-3 $\alpha$-OL,20-ONE $(3 \alpha, 5 \beta-T H P)$

Figure 1 Partial schematic representation of the progesterone metabolic pathway.

lambda and centered with respect to the midline). DRN 5-HT neurons unit activity was recorded by lowering the micropipette along descents covering the nucleus from $300 \mu \mathrm{m}$ to about $1500 \mu \mathrm{m}$ anterior of lambda. Spontaneously active DRN 5-HT neurons were identified according to the criteria of Aghajanian et al. (1978): a slow and regular rhythmical firing rate and positive action potentials of long duration.

For each group of rats, the basal firing rate of 5-HT neurons was calculated by averaging the firing rate of each neuron measured. This was achieved by recording, for at least $60 \mathrm{~s}$, each 5-HT neuron encountered in complete descents in the DRN of three to six rats.

\section{Statistics}

Statistical analysis were performed with the software SigmaStat for Windows Version 2.0 (Jandel Corporation, San Rafael, CA, USA). Average values are given as the means \pm S.E.M. One-way ANOVA, with alpha $=0 \cdot 05$, followed by a post-hoc analysis using Tukey's method of comparison vs control was used for evaluating statistical 
A)

Control (3\% ethanol)

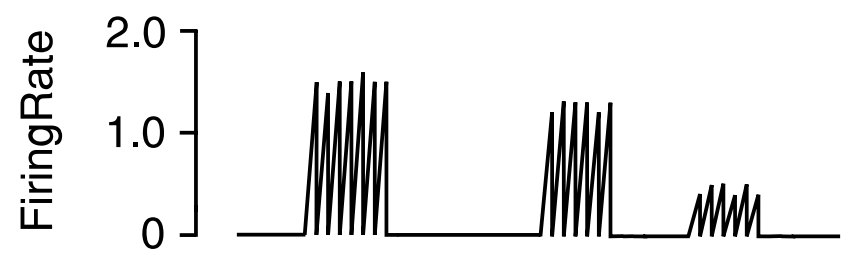

B)

\section{Progesterone}

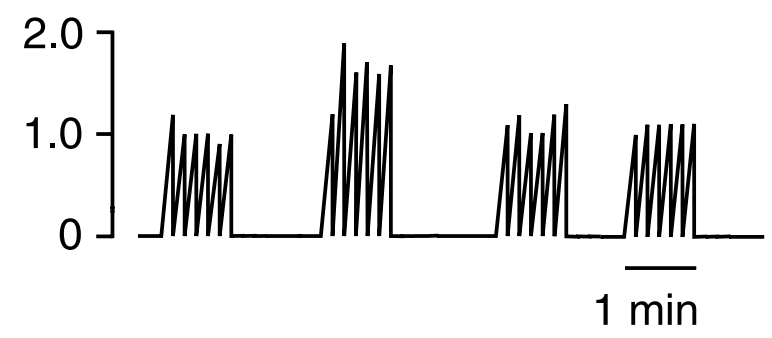

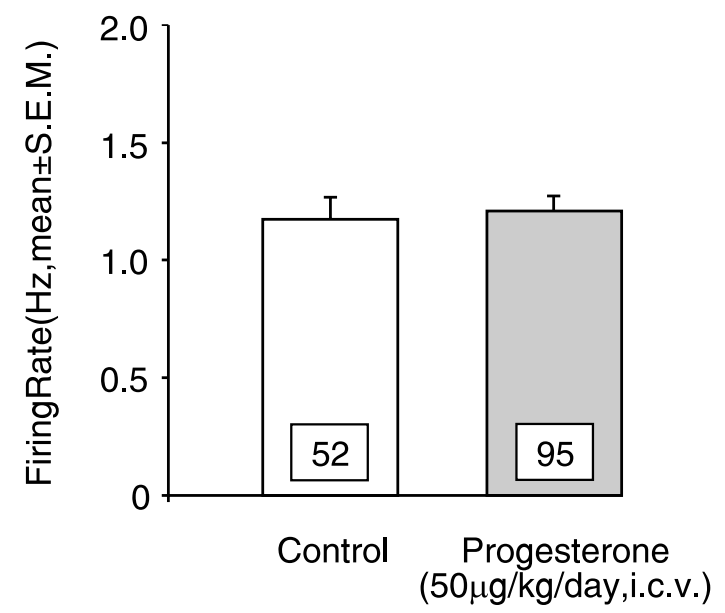

Figure 2 (A) Integrated firing rate histograms of 5-HT neurons, showing their spontaneous firing activity, recorded in one electrode descent in the DRN of female controls (3\% ethanol, i.c.v., 7 days) and following a treatment with progesterone (50 $\mu \mathrm{g} / \mathrm{kg}$ per day, i.c.v., 7 days). (B) Spontaneous firing rate of female DRN 5-HT neurons expressed in $\mathrm{Hz}$ (means \pm S.E.M.) in controls and following a 7 day treatment with progesterone. The number of neurons recorded is indicated in each box.

significance. Results $(\mathrm{F})$ of statistical analysis are expressed in terms of degrees of freedom between groups compared and number of groups compared. Significance was considered for $P<0 \cdot 05$.

\section{Drugs}

Trilostane was obtained from Sanofi Research Division (Malvern, PA, USA), NE-100 was kindly provided by Taisho Pharmaceutical Co. Ltd (Tokyo, Japan) and finasteride was prepared from $5 \mathrm{mg}$ commercial pills of Proscar (Merck Frosst, Kirkland, Québec, Canada). Steroids used were: progesterone, PREG, 5 $\beta$-DHP, $3 \alpha, 5 \beta$-THP, $3 \beta, 5 \beta$-THP, $5 \alpha$-DHP, $3 \alpha, 5 \alpha$-THP, $3 \beta, 5 \alpha-$ THP (Steraloid) and DHEA (Sigma, Newport, RI, USA).

\section{Results}

Two types of controls were separately carried out in order to assess the potential effect of the surgical procedure and of the vehicle. Since the surgical control (saline, i.c.v.) was very similar to FC $(1.01 \pm 0.07 \mathrm{~Hz}, n=70$, and $1 \cdot 02 \pm 0.07 \mathrm{~Hz}, n=72$ respectively (data not shown)), the vehicle control was used for comparison with the subsequent treatments. Progesterone, administered i.c.v. for 7 days to FC did not significantly modify the firing activity of 5 -HT neurons $(1 \cdot 21 \pm 0 \cdot 07 \mathrm{~Hz}, n=95$ vs $1 \cdot 18 \pm 0 \cdot 10$ $\mathrm{Hz}, n=52(\mathrm{~F}(1,2)=0 \cdot 09$, n.s. $))$ (Fig. 2).

Since in a previous series of experiments, OVX did not decrease the basal firing activity of 5-HT neurons (Klink et al. 2002), we decided to investigate if the cerebral de novo synthesis of progesterone was sufficient to maintain the basal 5-HT neuron activity. Thus, to prevent local progesterone synthesis, OVX rats were treated with trilostane (an inhibitor of the $3 \beta$-hydroxysteroid dehydrogenase, the enzyme responsible for converting PREG into progesterone, see Fig. 1). As reported before, the firing activity of 5-HT neurons was not significantly modified following OVX (as compared with FC $(\mathrm{F}(1,2)=1 \cdot 19 \pm$ $0 \cdot 12 \mathrm{~Hz}, n=43$ vs $1 \cdot 02 \pm 0 \cdot 07 \mathrm{~Hz}, n=72$, n.s.), Fig. $3 \mathrm{~A})$. Following the treatment with trilostane $(25 \mathrm{mg} / \mathrm{kg}$ per day 
A)

B)
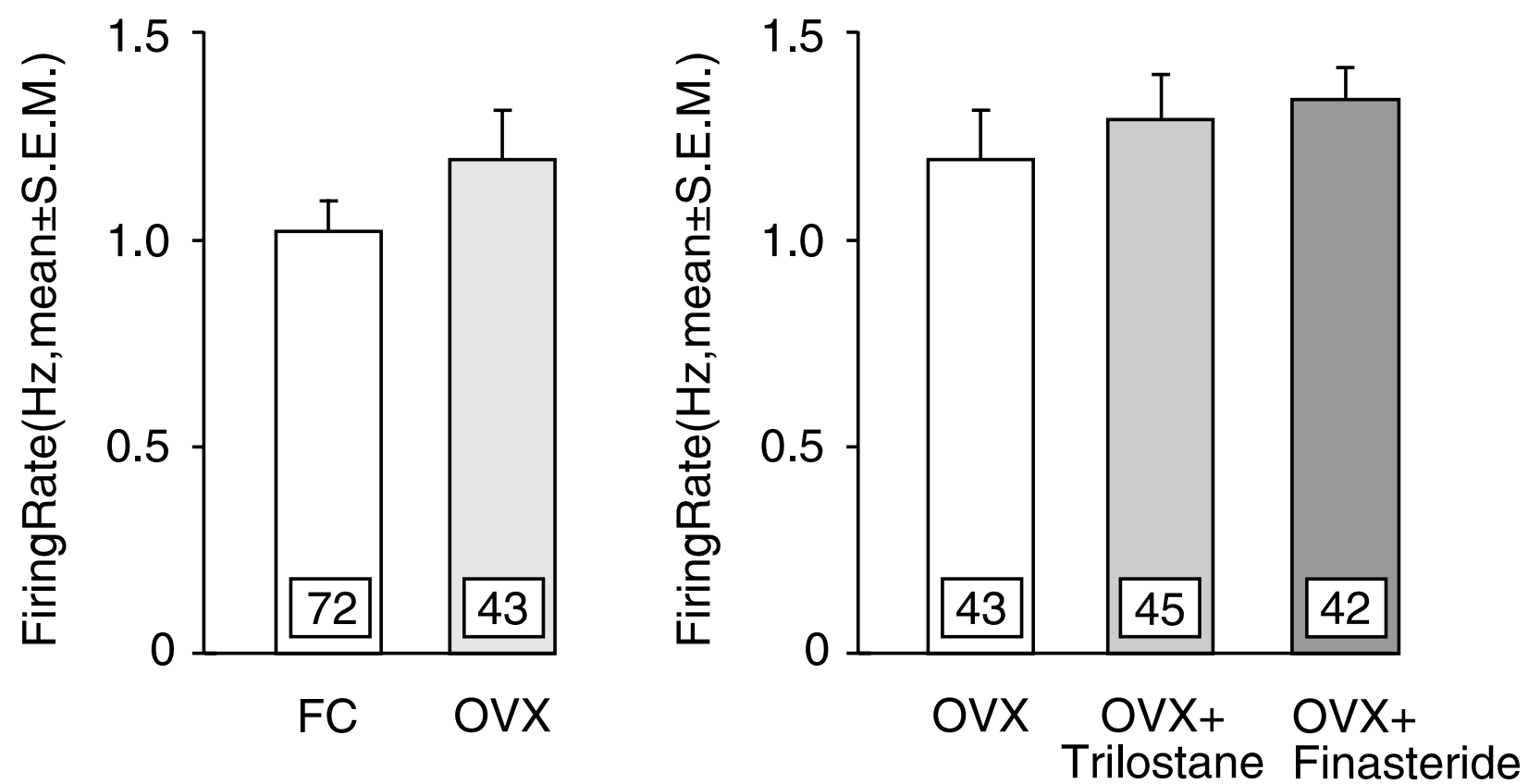

Figure 3 Spontaneous firing rate of DRN 5-HT neurons expressed in $\mathrm{Hz}$ (means \pm S.E.M.) in FC, OVX (A) and in OVX, OVX treated with trilostane for 14 days (OVX+trilostane, $25 \mathrm{mg} / \mathrm{kg}$ per day, s.c.) and OVX treated with finasteride for 5 days (OVX+finasteride, $20 \mathrm{mg} / \mathrm{kg}$ per day, p.o.) (B). The number of neurons recorded is indicated in each box.

for 14 days), the firing activity of $5-\mathrm{HT}$ neurons was increased by less than $10 \%$, which was not statistically significant as compared with OVX $(1 \cdot 29 \pm 0 \cdot 11 \mathrm{~Hz}$, $n=44$ and $1 \cdot 19 \pm 0 \cdot 12 \mathrm{~Hz}, n=43$ respectively $(\mathrm{F}(1,2)=$ $0 \cdot 37$, n.s.), Fig. 3B).

As another way to assess the capacity of the cerebral de novo synthesis of progesterone to influence the basal firing rate of DRN 5-HT neurons, OVX were treated with finasteride $(20 \mathrm{mg} / \mathrm{kg}$ per day for 5 days), a selective blocker of the $5 \alpha$-reductase (the enzyme metabolizing progesterone into $5 \alpha-\mathrm{DHP}$, see Fig. 1). This was done to prevent the catabolism of progesterone and, therefore, to increase its cerebral levels. Increasing progesterone levels with finasteride did not significantly increase 5-HT neuron firing activity as compared with OVX $(1.34 \pm 0.08 \mathrm{~Hz}$, $n=42$ and $1 \cdot 19 \pm 0 \cdot 12 \mathrm{~Hz}, n=43$ respectively $(\mathrm{F}(1,2)=$ $1 \cdot 00$, n.s.), Fig. 3B).

Since progesterone does not seem to affect the firing activity of 5-HT neurons, the effects of its precursor and of some of its metabolites were investigated. As was the case with progesterone, a 7 day treatment with PREG led to a non-significant increase in 5 -HT neuronal firing rate $(1.52 \pm 0.17 \mathrm{~Hz}, n=55$ vs $1.19 \pm 0.13 \mathrm{~Hz}, n=41$ $(F(1,2)=2 \cdot 07$, n.s. $)$, Fig. 4$)$.

In parallel to progesterone, DHEA is also synthesized from PREG (Fig. 1). The DHEA treatments led to an increase in firing activity, which persisted over time (Fig. 5). After 7 days, the mean firing frequency of 5-HT neurons was increased from $0.96 \pm 0.08 \mathrm{~Hz}, n=52$, to

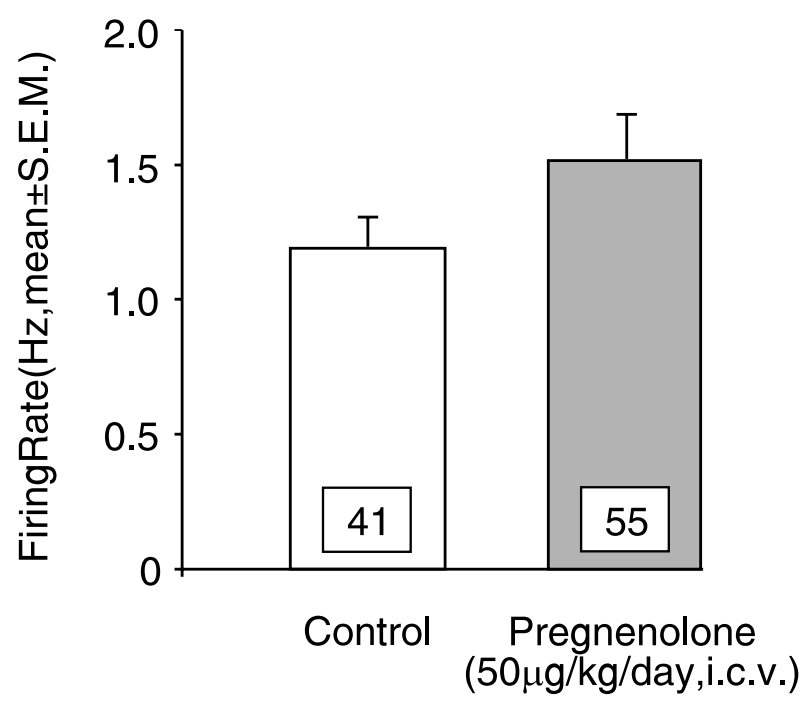

Figure 4 Spontaneous firing rate of female DRN 5-HT neurons expressed in $\mathrm{Hz}$ (means \pm S.E.M.) in controls ( $3 \%$ ethanol, 7 days, i.c.v.) and following a treatment with PREG ( $50 \mu \mathrm{g} / \mathrm{kg}$ per day, i.c.v., 7 days). The number of neurons recorded is indicated in each box. 


\section{3\% Ethanol (i.c.v.) \\ DHEA $(50 \mu \mathrm{g} / \mathrm{kg} /$ day,i.c.v. $)$}

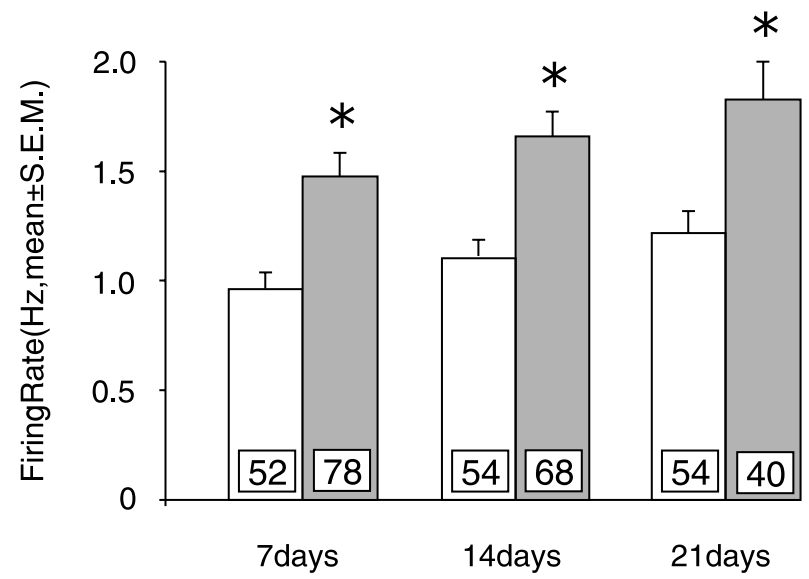

Figure 5 Spontaneous firing rate of female DRN 5-HT neurons expressed in $\mathrm{Hz}$ (means \pm S.E.M.) following different treatment durations with DHEA ( $50 \mu \mathrm{g} / \mathrm{kg}$ per day, i.c.v.) or $3 \%$ ethanol (i.c.v.) for the controls. The stars indicate $P<0.01$ as compared with the respective control. The number of neurons recorded is indicated in each box.

$1 \cdot 48 \pm 0 \cdot 11 \mathrm{~Hz}, n=78(\mathrm{~F}(5,6)=7 \cdot 92, P<0 \cdot 001$, Tukey's test, $\mathrm{q}=4 \cdot 8, P<0 \cdot 01)$, after 14 days, it was increased from $1 \cdot 10 \pm 0.09 \mathrm{~Hz}, \quad n=54$ to $1 \cdot 66 \pm 0 \cdot 11 \mathrm{~Hz}, \quad n=68$ $(\mathrm{F}(5,6)=7 \cdot 92, P<0 \cdot 001$, Tukey's test, $\mathrm{q}=5 \cdot 1, P<0 \cdot 01)$, and after 21 days it reached $1 \cdot 82 \pm 0 \cdot 18 \mathrm{~Hz}, n=40$ as compared with $1 \cdot 21 \pm 0 \cdot 11 \mathrm{~Hz}, n=54 \quad(\mathrm{~F}(5,6)=7 \cdot 92$, $P<0 \cdot 001$, Tukey's test, $\mathrm{q}=4 \cdot 9, P<0 \cdot 01)$.

Since the increase in 5-HT neuron firing activity, measured following progesterone treatments, was not present as expected from the results obtained during pregnancy (Klink et al. 2002), the possible implication of different progesterone metabolites was investigated. First, females were treated for 7,14 and 21 days with $5 \beta$-DHP. The 7 day treatment led to a significant increase in 5 -HT neuron basal firing rate $(1.64 \pm 0 \cdot 11 \mathrm{~Hz}, n=45$ $(\mathrm{F}(5,6)=7 \cdot 01, P<0 \cdot 001$, Tukey's test, $\mathrm{q}=6 \cdot 0, P<0 \cdot 01)$, Fig. 6). This was followed by a gradual decrease towards control values (Fig. 6); after 14 days of administration, the increase in firing rate was still statistically significant as compared with its control $(1.57 \pm 0.09 \mathrm{~Hz}, n=78$, vs $1 \cdot 10 \pm 0.08 \mathrm{~Hz}, \quad n=63, \quad(\mathrm{~F}(5,6)=7 \cdot 01, \quad P<0 \cdot 001$, Tukey's test, $\mathrm{q}=5 \cdot 2, P<0 \cdot 01)$ ) but not after 21 days of treatment $(1 \cdot 16 \pm 0.13 \mathrm{~Hz}, n=55$, vs $1 \cdot 22 \pm 0 \cdot 11 \mathrm{~Hz}$, $n=46 \quad(\mathrm{~F}(5,6)=7 \cdot 01, \quad P<0 \cdot 001$, Tukey's test, $\mathrm{q}=0 \cdot 6$, n.s.)).

The enzymes converting $5 \beta$-DHP into its metabolites $3 \alpha, 5 \beta-$ THP and $3 \beta, 5 \beta-$ THP are present in the brain (Celotti et al. 1992, Guennoun et al. 1995). Therefore, FC were administered for 7 days with these metabolites but neither treatment led to a statistically significant increase in

\section{$3 \%$ Ethanol (i.c.v.) \\ $5 \beta-\mathrm{DHP}(50 \mu \mathrm{g} / \mathrm{kg} /$ day,i.c.v. $)$}

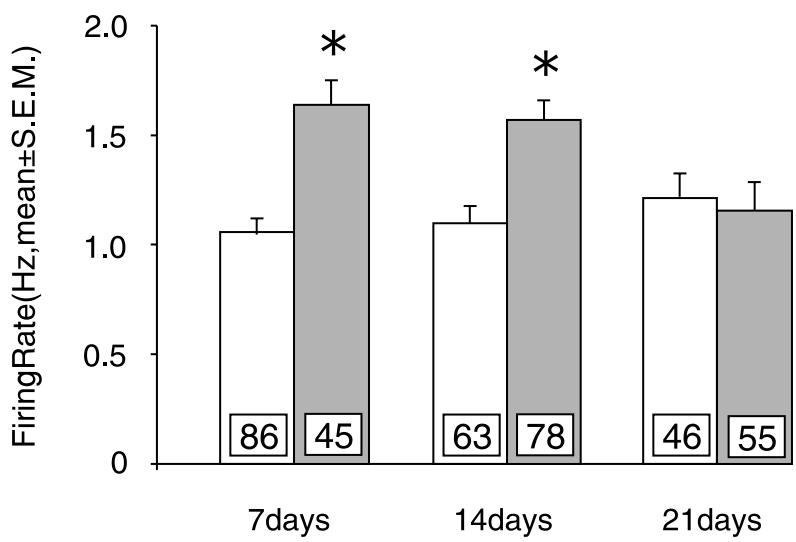

Figure 6 Spontaneous firing rate of female DRN 5-HT neurons expressed in $\mathrm{Hz}$ (means \pm S.E.M.) following different treatment durations with $5 \beta$-DHP $(50 \mu \mathrm{g} / \mathrm{kg}$ per day, i.c.v.) or $3 \%$ ethanol (i.c.v.) for the controls. The stars indicate $P<0 \cdot 01$ as compared with the respective control. The number of neurons recorded is indicated in each box.

the firing rate of 5-HT neurons as compared with controls

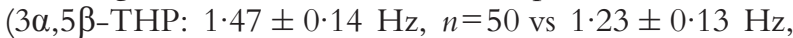
$n=47(\mathrm{~F}(1,2)=1.52$, n.s. $)$ and $3 \beta, 5 \beta$-THP: $1.51 \pm 0 \cdot 12$ $\mathrm{Hz}, n=68$ vs $1.23 \pm 0.13 \mathrm{~Hz}, n=47(\mathrm{~F}(1,2)=2 \cdot 39$, n.s. $)$, Fig. 7).

The effect of the other progesterone metabolite stereoisomers was also investigated. FC received a 7 day administration of $5 \alpha$-DHP, $3 \alpha, 5 \alpha-$ THP and $3 \beta, 5 \alpha-$ THP

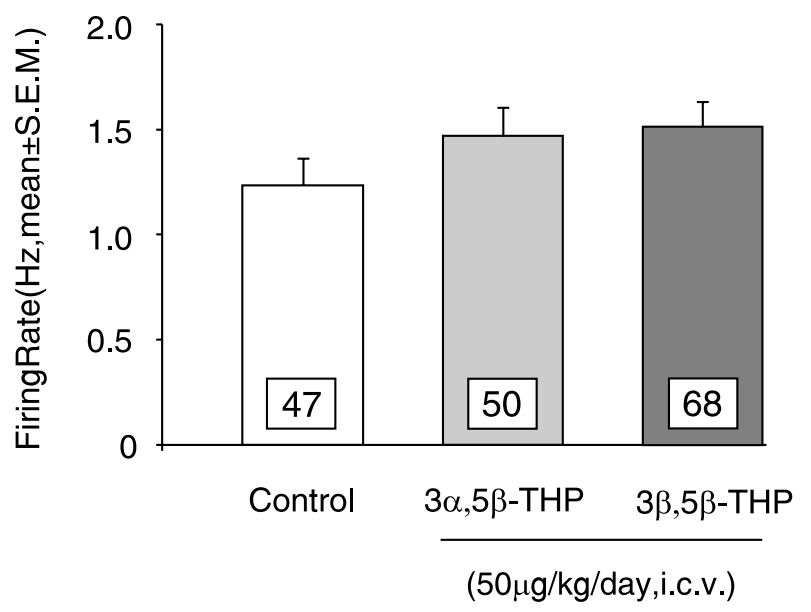

Figure 7 Spontaneous firing rate of female DRN 5-HT neurons expressed in $\mathrm{Hz}$ (means \pm S.E.M.) in controls (3\% ethanol, i.c.v.) and following a 7 day treatment with either $3 \alpha, 5 \beta$-THP $(50 \mu \mathrm{g} / \mathrm{kg}$ per day, i.c.v.) or $3 \beta, 5 \beta-\mathrm{THP}(50 \mu \mathrm{g} / \mathrm{kg}$ per day, i.c.v.). The number of neurons recorded is indicated in each box. 


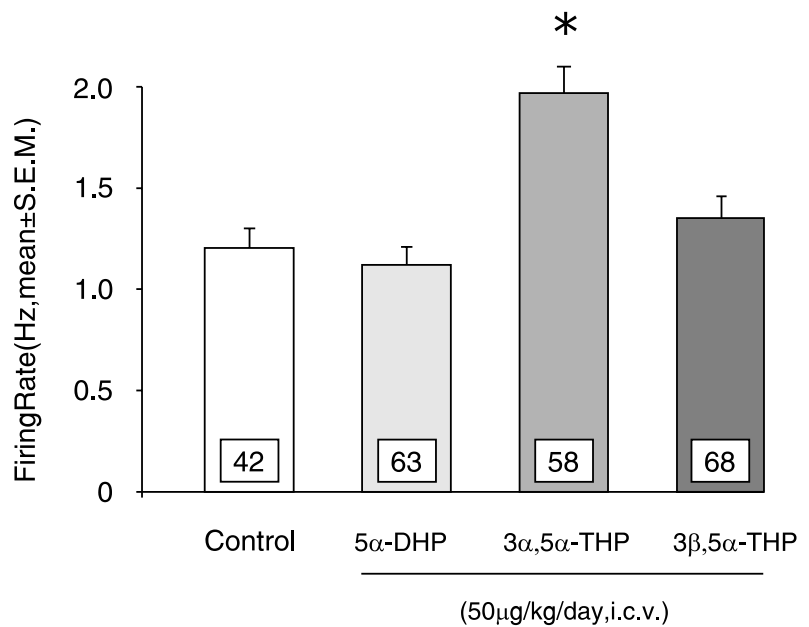

Figure 8 Spontaneous firing rate of female DRN 5-HT neurons expressed in $\mathrm{Hz}$ (means \pm S.E.M.) in controls (3\% ethanol) and following a 7 day treatment with either $5 \alpha$-DHP, $3 \alpha, 5 \alpha$-THP or $3 \beta, 5 \alpha$-THP ( $50 \mu \mathrm{g} / \mathrm{kg}$ per day, i.c.v., in each case). The star indicates $P<0 \cdot 001$. The number of neurons recorded is indicated in each box.

(Fig. 8). Neither $5 \alpha-$ DHP nor its metabolite $3 \beta, 5 \alpha$-THP significantly modified the firing activity of 5 -HT neurons $(1 \cdot 12 \pm 0.09 \mathrm{~Hz}, n=63(\mathrm{~F}(1,2)=0.33$, n.s. $)$ and $1.35 \pm$ $0 \cdot 11 \mathrm{~Hz}, n=75(\mathrm{~F}(1,2)=0 \cdot 80$, n.s. $)$ respectively as compared with $1 \cdot 20 \pm 0 \cdot 10 \mathrm{~Hz}, n=42$ for the controls). However, $3 \alpha, 5 \alpha$-THP induced a pronounced increase in their firing rate $(1.97 \pm 0.13 \mathrm{~Hz}, n=58$ compared with $1 \cdot 20 \pm 0 \cdot 10 \mathrm{~Hz}, n=42(\mathrm{~F}(1,2)=18 \cdot 23, P<0 \cdot 001))$.

DHEA has been shown to have agonistic properties at $\sigma$ receptors in a model using the $\mathrm{N}$-methyl-D-aspartate response in the hippocampus (Bergeron et al. 1996, Debonnel et al. 1996). For this reason, FC were treated simultaneously with DHEA and the selective $\sigma_{1}$ antagonist NE-100 to investigate if the higher firing rate induced by DHEA was mediated by $\sigma_{1}$ receptors. NE-100, at a dose shown to block the effect of other $\sigma$ ligands (Bermack \& Debonnel 2001), prevented the increase in firing rate induced by DHEA (controls: $0.96 \pm 0.08 \mathrm{~Hz}, n=52$; DHEA: $1 \cdot 48 \pm 0 \cdot 11 \mathrm{~Hz}, n=78(\mathrm{~F}(2,3)=6 \cdot 22, P<0 \cdot 005$, Tukey's test, $\mathrm{q}=5 \cdot 0, \quad P<0 \cdot 05) ; \quad$ DHEA+NE-100: $1 \cdot 22 \pm 0 \cdot 10 \mathrm{~Hz}, n=70(\mathrm{~F}(2,3)=6 \cdot 22, P<0 \cdot 005$, Tukey's test, $q=2 \cdot 5$, n.s.), Fig. 9) indicating that this effect was mediated by $\sigma_{1}$ receptors. Because the effect of $5 \beta$ DHP had a different time-frame, as compared with that of DHEA, the implication of $\sigma_{1}$ receptors was also investigated for this steroid. However, NE-100 did not prevent the $5 \beta$-DHP-induced increase in firing rate (controls: $1 \cdot 06 \pm 0.07 \mathrm{~Hz}, n=86$; $5 \beta$-DHP: $1.64 \pm 0 \cdot 11$ $\mathrm{Hz}, n=45(\mathrm{~F}(2,3)=14 \cdot 95, P<0 \cdot 001$, Tukey's test, $\mathrm{q}=6 \cdot 4$, $P<0 \cdot 05) ; \quad 5 \beta-\mathrm{DHP}+\mathrm{NE}-100: \quad 1 \cdot 67 \pm 0 \cdot 14 \mathrm{~Hz}, \quad n=40$ $(\mathrm{F}(2,3)=6 \cdot 23, P<0 \cdot 001$, Tukey's test, $\mathrm{q}=6 \cdot 2, P<0 \cdot 05)$, Fig. 10).

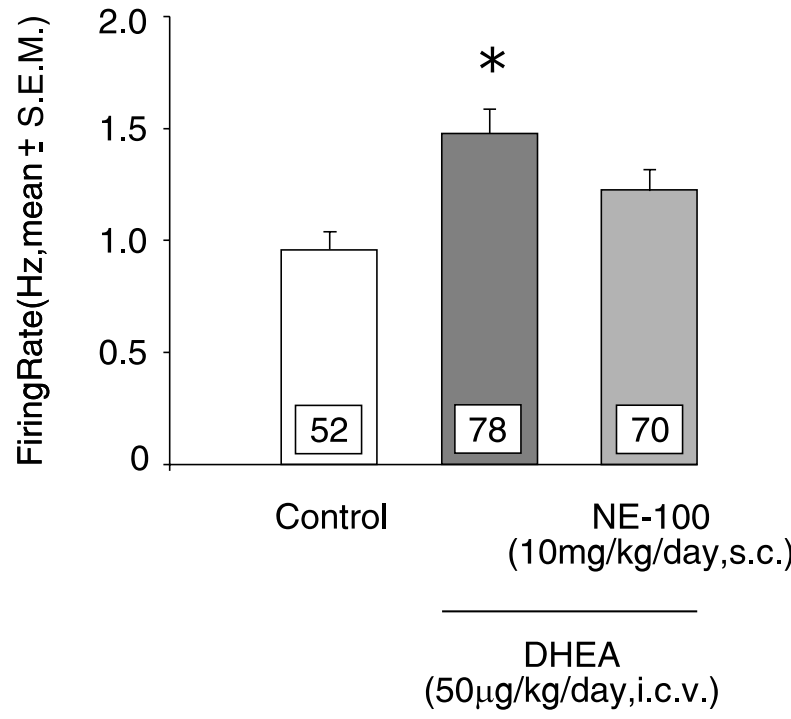

Figure 9 Spontaneous firing rate of female DRN 5-HT neurons expressed in $\mathrm{Hz}$ (means \pm S.E.M.) in controls (3\% ethanol) and following a 7 day treatment with either DHEA ( $50 \mu \mathrm{g} / \mathrm{kg}$ per day, i.c.v.) or both DHEA (50 $\mu \mathrm{g} / \mathrm{kg}$ per day, i.c.v.) and NE-100 $(10 \mathrm{mg} / \mathrm{kg}$ per day, s.c.). The star indicates $P<0 \cdot 05$. The number of neurons recorded is indicated in each box.

\section{Discussion}

The main findings of this study are (i) the increase in the firing activity of female 5-HT neurons following the

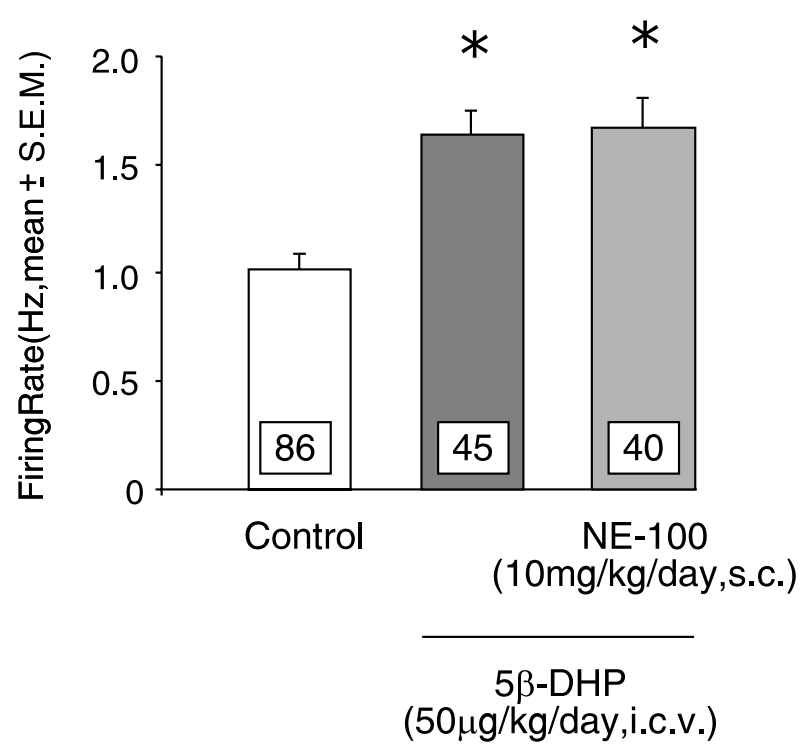

Figure 10 Spontaneous firing rate of female DRN 5-HT neurons expressed in $\mathrm{Hz}$ (means \pm S.E.M.) in controls ( $3 \%$ ethanol) and following a 7 day treatment with either $5 \beta$-DHP $(50 \mu \mathrm{g} / \mathrm{kg}$ per day, i.c.v.) or both $5 \beta$-DHP $(50 \mu \mathrm{g} / \mathrm{kg}$ per day, i.c.v.) and NE-100 $(10 \mathrm{mg} / \mathrm{kg}$ per day, s.c.). The stars indicate $P<0 \cdot 05$. The number of neurons recorded is indicated in each box. 
Table 1 Summary of the effect of each steroid after a 7 day treatment $(50 \mu \mathrm{g} / \mathrm{kg}$ per day, i.c.v.) on the firing activity of female DRN 5-HT neurons. Only statistically significant increases are identified by upward arrows

Effect on the firing activity of 5-HT neurons

Steroid
Progesterone
Pregnenolone
DHEA
$5 \beta$-DHP
$3 \alpha, 5 \beta-T H P$
$3 \beta, 5 \beta-T H P$
$5 \alpha$-DHP
$3 \alpha, 5 \alpha-$ THP
$3 \beta, 5 \beta-T H P$

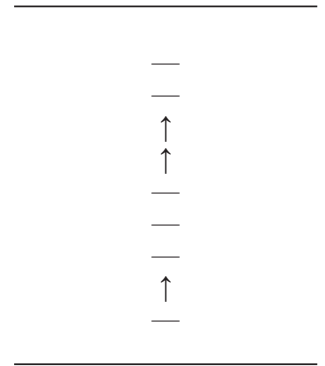

chronic administration of some neuroactive steroids, i.e. $5 \beta$-DHP, $3 \alpha, 5 \alpha$-THP and DHEA (Table 1) and (ii) the effect of DHEA but not of 5 $\beta$-DHP is mediated, at least in part, by $\sigma_{1}$ receptors. Furthermore, the larger effects of some metabolites compared with those of progesterone, and the fact that progesterone is rapidly metabolized in the brain, suggests that the metabolites may play an important role in the modulation of the 5-HT neuronal activity.

In a previous study, we have shown that during pregnancy the spontaneous firing rate of 5-HT neurons is more than doubled (Klink et al. 2002). Moreover, the firing activity of 5-HT neurons changes in parallel with the plasma levels of progesterone (Klink et al. 2002). Our hypothesis was therefore that progesterone could be responsible for increasing the 5-HT neuronal activity in females. However, in OVX rats, the plasma levels of progesterone are much lower than in FC, while the firing rate of DRN 5-HT neurons is unchanged when compared with FC (Klink et al. 2002). This was suggesting that the de novo synthesis of progesterone, which is known to occur in the brain (Guennoun et al. 1995), might be sufficient to maintain a normal level of the 5-HT neuron firing activity following OVX.

In rats treated with progesterone for 7 days, the absence of significant modification of the firing activity indicates that progesterone is probably not directly involved in the increase of 5-HT neuronal firing activity observed during pregnancy. Based on the literature, cerebral concentrations were extrapolated to be about four times higher than that reached by progesterone during pregnancy (Corpéchot et al. 1993) and are thus in the high physiological range. However, progesterone was administered only for 7 days and an effect of progesterone following a longer treatment cannot be ruled out.

Surprisingly, blocking cerebral progesterone synthesis in OVX rats, with a trilostane treatment, did not decrease the firing activity of the 5-HT neurons and there was even a trend towards an increase. Using different in vivo paradigms, similar or lower doses of trilostane were shown to efficiently inhibit the enzyme $3 \beta$-hydroxysteroid dehydrogenase (Potts et al. 1978, Young et al. 1994, Phan et al. 1999, Micevych et al. 2003). A possible explanation was thus that the blockade of progesterone synthesis could lead to a shift of the biosynthesis equilibrium towards a greater synthesis of DHEA (see Fig. 1). Rats were therefore treated with the precursor PREG as well as with DHEA. Administration of DHEA, but not of PREG, resulted in an enhanced firing activity of the DRN 5-HT neurons, which is in keeping with our hypothesis. Moreover, this DHEA-induced increase in 5-HT neuronal firing rate might explain the antidepressant effect observed with DHEA in humans (Wolkowitz et al. 1997).

Another way to assess the possible effect of the local progesterone de novo synthesis was to block its catabolism, therefore increasing progesterone cerebral levels in OVX rats. Finasteride, a selective $5 \alpha$-reductase inhibitor, was used for this purpose. It has previously been shown that the systemic administration of similar doses of finasteride efficiently blocks the enzymatic activity of cerebral $5 \alpha-$ reductase (Phan et al. 1999). However, in our hands, this treatment did not significantly change the 5-HT neuron basal firing rate. This constitutes another indication that, contrary to our previous hypothesis, progesterone by itself is not involved directly in the control of the firing activity of DRN 5-HT neurons. This is also in keeping with the demonstration that following OVX, despite local progesterone synthesis, the cerebral content of progesterone was decreased by more than 70\% (Corpéchot et al. 1993) but that there was no change in the firing activity of 5-HT neurons. Therefore, it appears that neurosteroids, other than progesterone, are involved in the modification of the firing activity of DRN 5-HT neurons observed during pregnancy.

Progesterone can be metabolized into $5 \alpha-\mathrm{DHP}$ and $5 \beta$-DHP by the $5 \alpha$ - and $5 \beta$-reductase respectively, and then further reduced into $3 \alpha, 5 \alpha$-THP and $3 \alpha, 5 \beta$-THP by the enzyme $3 \alpha$-hydroxysteroid oxidoreductase $(3 \alpha-$ HSOD) (Kawahara et al. 1975, Karavolas \& Hodges 1991, Celotti et al. 1992, Compagnone \& Mellon 2000). These three enzymes ( $5 \alpha-$ and $5 \beta$-reductases, and $3 \alpha$-HSOD) are present, and active, in the mammalian brain (Kawahara et al. 1975, 1981, Celotti et al. 1992). It appears that the principal metabolic pathway for cerebral progesterone is its reduction into $5 \alpha$-DHP and $3 \alpha, 5 \alpha$-THP (Karavolas $\&$ Hodges 1991, Korneyev et al. 1993) (see Fig. 1). Interestingly, $3 \alpha, 5 \alpha$-THP was the most potent steroid of the present study. Since this steroid is probably the principal metabolite of progesterone, its levels may be elevated enough during pregnancy to substantially contribute to the increase in the firing activity of 5-HT neurons observed in pregnant rats.

A rather unexpected finding of this study was the different time-frame for the increase in firing activity of 
the 5 -HT neurons caused by $5 \beta-\mathrm{DHP}$ and DHEA. The $5 \beta$-DHP-induced increase in firing activity was maximal after a 7 day treatment, followed by a gradual decline to finally lose statistical significance after 21 days of administration. On the other hand, the enhancement of the firing rate caused by DHEA was sustained over the 21 day period of time. This would support the hypothesis that more than one receptor is implicated in the effects seen with the different steroids tested in this study. Indeed, the DHEA-induced enhancement of the firing activity of 5-HT neurons seems to be mediated, at least in part, by $\sigma_{1}$ receptors, as shown by the fact that co-administration of the $\sigma_{1}$ receptor antagonist NE-100 prevented this effect. Interestingly, other $\sigma$ ligands have been shown to increase the firing rate of 5-HT neurons in similar period of times and this effect could be blocked by NE-100 (Bermack \& Debonnel 2001, 2004). Furthermore, the present results could suggest a physiological basis to the antidepressantlike effects observed for some neuroactive steroids in an animal model of depression, which effects were also shown to be mediated by $\sigma_{1}$ receptors (Reddy et al. 1998, Urani et al. 2001). On the other hand, NE-100 did not prevent the effect of $5 \beta-\mathrm{DHP}$, thus indicating that other receptor(s) must mediate it. Also, the time-frame for the $5 \beta$ DHP-induced increase in firing activity could suggest a functional desensitization of the receptor mediating the effect of $5 \beta-\mathrm{DHP}$ on 5 -HT neurons, whereas in the case of DHEA, there is no such indication, which is also in agreement with what is found with other $\sigma$ ligands (Bermack \& Debonnel 2001).

The mechanism(s) by which progesterone metabolites increase the firing activity of 5-HT neurons is still unclear. However, based on our previous studies with pregnant rats, a partial desensitization of $5-\mathrm{HT}_{1 \mathrm{~A}}$ autoreceptors appears as a likely component (Robichaud et al. 2002). If neurosteroids, whose levels rise dramatically during pregnancy, are indeed responsible for the pregnancy-induced desensitization of $5-\mathrm{HT}_{1 \mathrm{~A}}$ autoreceptors, the intracerebral administration of neuroactive steroids could also lead to such desensitization. Since $5-\mathrm{HT}_{1 \mathrm{~A}}$ autoreceptors are inhibitory, their partial desensitization would easily explain the enhanced firing activity of 5-HT neurons reported in the present study.

On the other hand, recent studies have shown that DHEA promotes neurogenesis in the hippocampal dentate gyrus and protects it from glucocorticoids' detrimental effects (Karishma \& Herbert 2002). Interestingly, Santarelli et al. (2003) showed that inhibition of hippocampal neurogenesis prevents the behavioral effects of antidepressants in different animal models of depression. Together, these data offer another mechanism of action for the antidepressant effect of DHEA (Kaminska et al. 2000). Further studies assessing the effect of other steroids on neurogenesis would be needed to assess whether this mechanism of action is specific to DHEA or if it might extend to other neurosteroids.
The effect of neuroactive steroids on 5-HT neurons activity could also be mediated through their interaction with $\mathrm{GABA}_{\mathrm{A}}$ receptors. It is well-known that $3 \alpha$-reduced steroids are $\mathrm{GABA}_{\mathrm{A}}$ receptor modulators and can even act as proper agonists (Harrison et al. 1987, Morrow et al. 1989, Puia et al. 1990, McCauley et al. 1995). Progesterone, 5aand $5 \beta$-DHP, devoid of such properties, are, however, rapidly converted into $3 \alpha, 5 \alpha-$ and $3 \alpha, 5 \beta$-THP, which can act on $\mathrm{GABA}_{\mathrm{A}}$ receptors (Bitran et al. 1993, Lancel et al. 1996). In rats, GABAergic neurons exert a tonic inhibition of DRN 5-HT neurons which seems to be mediated mostly by $\mathrm{GABA}_{\mathrm{A}}$ receptors (Innis \& Aghajanian 1987, Smith \& Gallager 1987, Gervasoni et al. 2000). Interestingly, during pregnancy, the GABAergic tonic inhibition of the 5-HT neurons was dramatically reduced when compared with that of FC (Robichaud et al. 2002). Also, accumulating evidence suggests that sustained high levels of neuroactive steroids reduce $\mathrm{GABA}_{\mathrm{A}}$ receptor responsiveness and the efficacy of modulators to potentiate the chloride influx (Friedman et al. 1993, Yu \& Ticku 1995a,b, Yu et al. 1996, Concas et al. 1998, Gulinello et al. 2001). It is thus possible that sustained neurosteroids administration could cause both a desensitization of $\mathrm{GABA}_{\mathrm{A}}$ receptors and/or a diminution of the tonic GABAergic inhibition on 5-HT neurons and thus increase the firing activity of these neurons. Interestingly, $3 \alpha, 5 \alpha-$ THP has the most potent agonistic properties on $\mathrm{GABA}_{\mathrm{A}}$ receptors and induced the greatest increase in 5-HT neuron firing activity, whereas progesterone and 5a-DHP were devoid of significant effect, which is in keeping with this hypothesis.

The CSF and plasma of depressed patients have been shown to contain lower levels of $3 \alpha, 5 \beta$-THP and $3 \alpha, 5 \alpha-$ THP than those of healthy volunteers, which could be brought back up to normal levels by successful antidepressant treatments (Romeo et al. 1998, Uzunova et al. 1998, Ströhle et al. 1999). No differences in progesterone levels were observed (Romeo et al. 1998, Uzunova et al. 1998). Lower serum levels of $3 \alpha, 5 \alpha$-THP were observed both in women suffering from premenstrual syndrome, during the luteal phase of their menstrual cycle, and in women with postpartum blues as compared with corresponding controls (Rapkin et al. 1997, Nappi et al. 2001). It was suggested that fluoxetine and other SSRIs interact with the enzyme $3 \alpha-\mathrm{HSD}$, responsible for the reversible conversion of $5 \alpha-$ and $5 \beta$-DHP into their respective $3 \alpha$-reduced metabolites $(3 \alpha, 5 \alpha-$ and $3 \alpha, 5 \beta-T H P)$. This interaction would favor the reduction reaction and would reduce the rate of the oxidative reaction (i.e. conversion of $3 \alpha, 5 \alpha-$ and $3 \alpha, 5 \beta-$ THP into $5 \alpha-$ and $5 \beta-\mathrm{DHP}$ ), thus leading to enhanced levels of $3 \alpha, 5 \alpha-$ and $3 \alpha, 5 \beta-$ THP (Uzunov et al. 1996, Uzunova et al. 1998, Griffin \& Mellon 1999).

Together, these studies could suggest an association between depressive states with a decrease in $3 \alpha, 5 \alpha$-THP levels, and mood improvement with an enhancement of the steroid levels. In agreement with this hypothesis, our results show that $3 \alpha, 5 \alpha$-THP significantly increases the 
5-HT neuron firing activity in females. Since all antidepressant treatments increase the efficacy of the 5-HT neurotransmission, these results could suggest a potential antidepressant effect for some neuroactive steroids.

Even if a clear link has not yet been firmly established, recent reports have suggested that hormonal replacement therapy (HRT) could induce undesirable side effects (see review by Armitage et al. 2003), which has led many patients to stop their HRT treatments. Natural hormones might, therefore, not be the best candidates as long-term adjuvants for antidepressant treatments, which would have to be administered presumably for several years to patients suffering from refractory depression. However, synthetic compounds having a similar pharmacological profile and the same effects on 5-HT neurons, which could be administered systemically, become interesting candidates. Therefore, the modulation by neurosteroids of the firing activity of 5-HT neurons, reported here, may prove important for the treatment of female mood disorders.

\section{Acknowledgements}

We thank Sanofi Research Division for providing us with trilostane and Taisho Pharmaceutical Co. Ltd for the gift of NE-100.

\section{Funding}

This work was supported by Fonds de la Recherche en Santé du Québec and we declare that no conflict of interest could prejudice the impartiality of this manuscript.

\section{References}

Armitage M, Nooney JM \& Evans S 2003 Recent concerns surrounding HRT. Clinical Endocrinology 59 145-155.

Bergeron R, De Montigny C \& Debonnel G 1996 Potentiation of neuronal NMDA response induced by dehydroepiandrosterone and its suppression by progesterone: effects mediated via sigma receptors. Journal of Neuroscience 16 1193-1202.

Bermack JE \& Debonnel G 2001 Modulation of serotonergic neurotransmission by short- and long-term treatments with sigma ligands. British Journal of Pharmacology 134 691-699.

Bethea CL, Pecins-Thompson M, Schutzer WE, Gundlah C \& Lu ZN 1999 Ovarian steroids and serotonin neural function. Molecular Neurobiology 18 87-123.

Bitran D, Purdy RH \& Kellogg CK 1993 Anxiolytic effect of progesterone is associated with increases in cortical allopregnanolone and $\mathrm{GABA}_{\mathrm{A}}$ receptor function. Pharmacology, Biochemistry, and Behavior 45 423-428.

Blier P \& de Montigny C 1999 Serotonin and drug-induced therapeutic responses in major depression, obsessive-compulsive and panic disorders. Neuropsychopharmacology 21 91S-98S.

Celotti F, Melcangi RC \& Martini L 1992 The $5 \alpha$-reductase in the brain: molecular aspects and relation to brain function. Frontiers in Neuroendocrinology 13 163-215.
Compagnone NA \& Mellon SH 2000 Neurosteroids: biosynthesis and function of these novel neuromodulators. Frontiers in Neuroendocrinology 21 1-56.

Concas A, Mostallino MC, Porcu P, Follesa P, Barbaccia ML, Trabucchi M, Purdy RH, Grisenti P \& Biggio G 1998 Role of brain allopregnanolone in the plasticity of $\gamma$-aminobutyric acid type A receptor in rat brain during pregnancy and after delivery. PNAS 95 13284-13289.

Corpéchot C, Young J, Calvel C, Veltz JN, Touyer G, Mouren M, Prasad VVK, Banner C, Sjovall J, Baulieu EE \& Robel P 1993 Neurosteroids: $3 \alpha$-hydroxy- $5 \alpha$-pregnan-20-one and its precursors in the brain, plasma, and steroidogenic glands of male and female rats. Endocrinology 133 1003-1009.

Debonnel G, Bergeron R \& De Montigny C 1996 Potentiation by dehydroepiandrosterone of the neuronal response to $\mathrm{N}$-methyl-D-aspartate in the $\mathrm{CA}_{3}$ region of the rat dorsal hippocampus: an effect mediated via sigma receptors. Journal of Endocrinology 150 S33-S42.

Dong E, Matsumoto K, Uzunova V, Sugaya I, Takahata H, Nomura H, Watanabe H, Costa E \& Guidotti A 2001 Brain $5 \alpha$-dihydroprogesterone and allopregnanolone synthesis in a mouse model of protracted social isolation. PNAS 98 2849-2854.

Endicott J 1993 The menstrual cycle and mood disorders. Journal of Affective Disorders 29 193-200.

Friedman L, Gibbs TT \& Farb DH 1993 - -Aminobutyric acid receptor regulation: chronic treatment with pregnanolone uncouples allosteric interactions between steroid and benzodiazepine recognition sites. Molecular Pharmacology 44 191-197.

Gervasoni D, Peyron C, Rampon C, Barbagli B, Chouvet G, Urbain N, Fort P \& Luppi P-H 2000 Role and origin of the GABAergic innervation of dorsal raphe nucleus serotonergic neurons. Journal of Neuroscience 20 4217-4225.

Griffin LD \& Mellon SH 1999 Selective serotonin reuptake inhibitors directly alter activity of neurosteroidogenic enzymes. PNAS 96 13512-13517.

Guennoun R, Fiddes RJ, Gouézou M, Lombès M \& Baulieu E-E 1995 A key enzyme in the biosynthesis of neurosteroids, $3 \beta$-hydroxysteroid dehydrogenase $/ \Delta^{5}-\Delta^{4}$-isomerase ( $3 \beta$-HSD), is expressed in rat brain. Molecular Brain Research 30 287-300.

Gulinello M, Gong QH, Li X \& Smith SS 2001 Short-term exposure to a neuroactive steroid increases $\alpha 4 \mathrm{GABA}_{\mathrm{A}}$ receptor subunit levels in association with increased anxiety in the female rat. Brain Research 910 55-66.

Hamilton JA 1993 Special aspects of neuropsychiatric illness in women: with a focus on depression. Annual Reviews of Medicine 44 355-364.

Harrison NL, Majewska MD, Harrington JW \& Barker JL 1987 Structure-activity relationships for steroid interaction with the $\gamma$-aminobutyric acid $_{\mathrm{A}}$ receptor complex. Journal of Pharmacology and Experimental Therapeutics 241 346-353.

Innis RB \& Aghajanian GK 1987 Pertussis toxin blocks 5-HT $1 \mathrm{~A}$ and $\mathrm{GABA}_{\mathrm{B}}$ receptor-mediated inhibition of serotonergic neurons. European Journal of Pharmacology 143 195-204.

Joffe H \& Cohen LS 1998 Estrogen, serotonin, and mood disturbance: where is the therapeutic bridge. Biological Psychiatry 44 798-811.

Kaminska M, Harris J, Gijsbers K \& Dubrovsky B 2000 Dehydroepiandrosterone sulfate (DHEAS) counteracts decremental effects of corticosterone on dentate gyrus LTP. Implications for depression. Brain Research Bulletin 52 229-234.

Karavolas HJ \& Hodges DR 1991 Metabolism of progesterone and related steroids by neural and neuroendocrine structures. In Neurosteroids and Brain Functions, pp 135-145. Eds E Costa \& SM Paul. New York: Theine.

Karishma KK \& Herbert J 2002 Dehydroepiandrosterone (DHEA) stimulates neurogenesis in the hippocampus of the rat, promotes survival of newly formed neurons and prevents corticosterone-induced suppression. European Journal of Neuroscience 16 445-453. 
Kawahara FS, Berman ML \& Green OC 1975 Conversion of progesterone- $1,2-{ }^{3} \mathrm{H}$ to $5 \beta$-pregnane- 3,20 -dione by brain tissue. Steroids 25 459-463.

Kessler RC, Mcgonagle KA, Zhao S, Nelson CB, Hughes M, Eshleman S, Wittchen H-U \& Kendler KS 1994 Lifetime and 12-month prevalence of DSM-III-R psychiatric disorders in the united states. Archives of General Psychiatry 51 8-19.

Klink R, Robichaud M \& Debonnel G 2002 Gender and gonadal status modulation of dorsal raphe nucleus serotonergic neurons. Part I: Effects of gender and pregnancy. Neuropharmacology 43 $1119-1128$.

Korneyev A, Guidotti A \& Costa E 1993 Regional and interspecies differences in brain progesterone metabolism. Journal of Neurochemistry 61 2041-2047.

Kornstein SG 1997 Gender differences in depression: implications for treatment. Journal of Clinical Psychiatry 58 12-18.

Lancel M, Faulhaber J, Holsboer F \& Rupprecht R 1996 Progesterone induces changes in sleep comparable to those of agonistic GABA receptor modulators. American Journal of Physiology 271 E763-E772.

Maes M, De Ruyter M, Hobin P \& Suy E 1986 The dexamethasone suppression test, the Hamilton depression rating scale and the DSM-III depression categories. Journal of Affective Disorders $\mathbf{1 0}$ 207-214.

McCauley LD, Liu V, Chen J-S, Hawkinson JE, Lan NC \& Gee KW 1995 Selective actions of certain neuroactive pregnanediols at the $\gamma$-aminobutyric acid type A receptor complex in rat brain. Molecular Pharmacology 47 354-362.

McEwen BS, Alves SE, Bulloch K \& Weiland NG 1998 Clinically relevant basic science studies of gender differences and sex hormone effects. Psychopharmacology Bulletin 34 251-259.

Micevych P, Sinchak K, Mills RH, Tao L, Lapolt P \& Lu JKH 2003 The luteinizing hormone surge is preceded by an estrogen-induced increase of hypothalamic progesterone in ovariectomized and adrenalectomized rats. Neuroendocrinology 78 29-35.

Morrow AL, Pace JR, Purdy RH \& Paul SM 1989 Characterization of steroid interactions with $\gamma$-aminobutyric acid receptor-gated chloride ion channels: evidence for multiple steroid recognition sites. Molecular Pharmacology 37 263-270.

Nappi RE, Petraglia F, Luisi S, Polatti F, Farina C \& Genazzani AR 2001 Serum allopregnanolone in women with postpartum 'blues'. Obstetrics and Gynecology 97 77-80.

Pajer KP 1995 New strategies in the treatment of depression in women. Journal of Clinical Psychiatry 56 30-37.

Parry BL 1989 Reproductive factors affecting the course of affective illness in women. Psychiatric Clinics of North America 12 207-220.

Phan V-L, Su T-P, Privat A \& Maurice T 1999 Modulation of steroidal levels by adrenalectomy/castration and inhibition of neurosteroid synthesis enzymes affect $\sigma_{1}$ receptor-mediated behaviour in mice. European Journal of Neuroscience 11 2385-2396.

Potts GO, Creange JE, Harding HR \& Schane HP 1978 Trilostane, an orally active inhibitor of steroid biosynthesis. Steroids $\mathbf{3 2}$ 257-267.

Puia G, Santi MR, Vicini S, Pritchett DB, Purdy RH, Paul SM, Seeburg PH \& Costa E 1990 Neurosteroids act on recombinant human $\mathrm{GABA}_{\mathrm{A}}$ receptors. Neuron 4 759-765.

Racagni G \& Brunello N 1999 Physiology to functionality: the brain and neurotransmitter activity. International Journal of Psychopharmacology 14 S3-S7.

Rapkin AJ, Morgan M, Goldman L, Brann DW, Simone D \& Mahesh VB 1997 Progesterone metabolite allopregnanolone in women with premenstrual syndrome. Obstetrics and Gynecology 90 709-714.

Reddy DS, Kaur G \& Kulkarni SK 1998 Sigma $\left(\sigma_{1}\right)$ receptor mediated antidepressant-like effects of neurosteroids in the Porsolt forced swim test. Neuroreport 9 3069-3073.

Robichaud M, Klink R \& Debonnel G 2002 Gender and gonadal status modulation of dorsal raphe nucleus serotonergic neurons. Part II: Regulatory mechanisms. Neuropharmacology 43 1129-1138.
Romeo E, Ströhle A, Spalletta G, Di Michele F, Hermann B, Holsboer F, Pasini A \& Rupprecht R 1998 Effects of antidepressant treatment on neuroactive steroids in major depression. American Journal of Psychiatry 155 910-913.

Santarelli L, Saxe M, Gross C, Surget A, Battaglia F, Dulawa S, Weisstaub N, Lee J, Duman R, Arancio O, Belzung C \& Hen R 2003 Requirements of hippocampal neurogenesis for the behavioral effects of antidepressants. Science 301 805-809.

Serra M, Pisu MG, Muggironi M, Parodo V, Papi G, Sari R, Dazzi L, Spiga F, Purdy RH \& Biggio G 2001 Opposite effects of shortversus long-term administration of fluoxetine on the concentrations of neuroactive steroids in rat plasma and brain. Psychopharmacology 158 48-54.

Smith D \& Gallager DW 1987 GABA, benzodiazepine and serotonergic receptor development in the dorsal raphe nucleus: electrophysiological studies. Brain Research 432 191-198.

Ströhle A, Romeo E, Hermann B, Pasini A, Spalletta G, Di Michele F, Holsboer F \& Rupprecht R 1999 Concentrations of 3a-reduced neuroactive steroids and their precursors in plasma of patients with major depression and after clinical recovery. Biological Psychiatry $\mathbf{4 5}$ 274-277.

Urani A, Roman FJ, Phan V-L, Su T-P \& Maurice T 2001 The antidepressant-like effect induced by sigma(1)-receptor agonists and neuroactive steroids in mice submitted to the forced swimming test. Journal of Pharmacology and Experimental Therapeutics 298 1269-1279.

Uzunov DP, Cooper TB, Costa E \& Guidotti A 1996 Fluoxetine-elicited changes in brain neurosteroid content measured by negative ion mass fragmentography. PNAS 93 12599-12604.

Uzunova V, Sheline Y, Davis JM, Rasmusson A, Uzunov DP, Costa E \& Guidotti A 1998 Increase in the cerebrospinal fluid content of neurosteroids in patients with unipolar major depression who are receiving fluoxetine or fluvoxamine. PNAS 95 3239-3244.

Weissman MM \& Klerman GL 1977 Sex differences and the epidemiology of depression. Archives of General Psychiatry 34 98-111.

Weissman MM \& Klerman GL 1985 Gender and depression. Trends in Neuroscience 8 416-420.

Weissman MM, Bland RC, Canino GJ, Faravelli C, Greenwald S, Hwu H-G, Joyce PR, Karam EG, Lee C-K, Lellouch J, Lépine J-P, Newman SC, Rubio-Stipec M, Wells JE, Wickramaratne PJ, Wittchen H-U \& Yeh E-K 1996 Cross-national epidemiology of major depression and bipolar disorder. Journal of the American Medical Association 276 293-299.

Wolkowitz OM, Reus VI, Roberts E, Manfredi F, Chan T, Raum WJ, Orniston S, Johnson R, Canick J, Brizendine L \& Weingartner H 1997 Dehydroepiandrosterone (DHEA) treatment of depression. Biological Psychiatry 41 305-310.

Young J, Corpéchot C, Perché F, Haug M, Baulieu EE \& Robel P 1994 Neurosteroids: pharmacological effects of a $3 \beta$-hydroxysteroid dehydrogenase inhibitor. Endocrine 2 505-509.

Yu R \& Ticku MK 1995a Chronic neurosteroid treatment produces functional heterologous uncoupling at the $\gamma$-aminobutyric acid type A/benzodiazepine receptor complex in mammalian cortical neurons. Molecular Pharmacology 47 603-610.

Yu R \& Ticku MK 1995b Chronic neurosteroid treatment decreases the efficacy of benzodiazepine ligands and neurosteroids at the $\gamma$-aminobutyric acid $_{\mathrm{A}}$ receptor complex in mammalian cortical neurons. Journal of Pharmacology and Experimental Therapeutics 275 784-789.

Yu R, Hay M \& Ticku MK 1996 Chronic neurosteroid treatment attenuates single cell $\mathrm{GABA}_{\mathrm{A}}$ response and its potentiation by modulators in cortical neurons. Brain Research 706 160-162.

Received 23 March 2004

Accepted 2 April 2004

Made available online as an

Accepted Preprint 15 April 2004 